\title{
DETERMINAN PSIKOLOGIS YANG BERHUBUNGAN DENGAN TERJADINYA HALUSINASI PENDENGARAN PADA PASIEN GANGGUAN JIWA DI RUANG RAWAT INAP RSJ PROF. DR. MUHAMMAD ILDREM TAHUN 2017
}

\author{
Endang Susilawati, Pondang Purba \\ Jurusan Keperawatan Poltekkes Kemenkes Medan
}

\begin{abstract}
Abstrak
Gangguan jiwa (mental disorder) merupakan salah satu dari empat masalah kesehatan utama di negaranegara maju. Penyakit yang menempati urutan empat besar adalah penyakit degeneratif, gangguan jiwa, dan kecelakan. Gangguan jiwa tidak dianggap sebagai gangguan yang menyebabkan kematian secara langsung, namun beratnya gangguan tersebut dalam arti ketidk mampuan serta invaliditas baik secara individu maupun kelompok akan menghambat pembangunan, karena mereka tidak produktif dan tidak efisien. Tujuan penelitian ini untuk mengetahui determinan psikologis yang berhubungan dengan terjadinya halusinasi pendengaran pada pasien gangguan jiwa di ruang rawt inap RSJ Prof. Dr. Muhammad Ildrem Medan tahun 2017. Jenis peneliti ini adalah analitik observasional yaitu untuk mencari hubungan antar variabel. Desain penelitian ini adalah cross sectional, yaitu penelitian yang pengukuran variabel-variabelnya dilakukan hanya satu kali, pada satu saat. Sampel dalam penelitian ini diambil dengan teknik systematic sampling besar sampel sebanyak 39 responden. Analisan datta menggunakan uji chi square, uji ini akan dilakukan dengan menggunakan aplikasi SPSS 16,0 dengan nilai signifikan $\mathrm{p}<0,15$. Hasil yang diperoleh dari penelitian ini menunjukkan adanya hubungan yang bermakna antara determinan psikologis terhadap terjadinya halusinasi pendengaran dengan nilai $\mathrm{p}$ value $=0,00$ dengan $(\mathrm{p}<0,15)$. Kesimpulan, ada hubungan antara determinan psikologis terhadap terjadinyahalusinasi pendengaran pada pasien gangguan jiwa.
\end{abstract}

Kata kunci : Determinan Psikologis, Halusinasi Pendengaran, Gangguan Jiwa

\section{A. Latar Belakang}

Kesehatan jiwa saat ini telah menjadi masalah kesehatan global bagi setiap negara termasuk Indonesia. Proses globalisasi dan pesatnya kemajuan teknologi informasi memberikan dampak terhadap nilai-nilai sosial dan budaya pada masyarakat. Di sisi lain, tidak semua orang mempunyai kemampuan yang sama untuk menyesuaikan dengan berbagai perubahan, serta mengelola konflik dan stres tersebut (Direktorat Bina Pelayanan Keperawatan dan Pelayanan Medik Dapertemen Kesehatan, 2007).

Gangguan jiwa (mental disorder) merupakan salah satu dari empat masalah kesehatan utama di negara-negara maju. Penyakit yang menempati urutan empat besar adalah penyakit degeneratif, kanker, gangguan jiwa, dan kecelakaan.

Gangguan jiwa tidak dianggap sebagai gangguan yang menyebabkan kematian secara langsung, namun beratnya gangguan tersebut dalam arti ketidakmampuan serta invaliditas baik secara individu maupun kelompok akan menghambat pembangunan, karena mereka tidak produktif dan tidak efisien (Hidayah, 2015). Gangguan jiwa menyebabkan penderitanya tidak sanggup menilai dengan baik kenyataan, tidak lagi menguasai dirinya untuk mencegah mengganggu orang lain atau merusak/menyakiti dirinya sendiri. Gangguan jiwa sesungguhnya sama dengan gangguan jasmaniah lainnya. Hanya saja gangguan jiwa bersifat lebih kompleks, mulai dari yang ringan seperti rasa cemas, takut hingga yang tingkat berat berupa sakit jiwa atau kita kenal sebagai gila (Madalise, 2015).

Kecenderungan gangguan jiwa akan semakin meningkat seiring dengan terus berubahnya situasi ekonomi dan politik kearah tidak menentu. Prevalensinya bukan saja pada kalangan menengah kebawah sebagai dampak langsung dari kesulitan ekonomi, tetapi juga kalangan menengah keatas sebagai dampak langsung atau tidak langsung dari kemampuan individu dalam penyesuaian diri terhadap perubahan sosial yang terus berubah (Madalise, 2015).

Menurut WHO (world health organization), jumlah penderita gangguan jiwa di dunia adalah 450 juta jiwa. Dengan mengacu data tersebut, kini jumlah itu diperkirakan sudah meningkat. Diperkirakan dari sekitar 220 juta penduduk Indonesia, ada sekitar 50 juta atau 22 persennya, mengidap gangguan kejiwaan. Data yang dikeluarkan oleh Badan Kesehatan Dunia/WHO (world health organization) pada tahun 2006 menyebutkan bahwa diperkirakan 26 juta penduduk indonesia mengalami 
gangguan kejiwaan, dari tingkat ringan hingga berat. Menurut data Departemen Kesehatan (2009), jumlah penderita gangguan jiwa saat ini, mencapai lebih dari 28 juta orang, dengan kategori gangguan jiwa ringan 11,6\% dan $0,46 \%$ menderita gangguan jiwa berat. Hasil penelitian WHO di Jawa Tengah menyebutkan dari 1000 warga Jawa Tengah terdapat 3 orang yang mengalami gangguan jiwa. Sementara 19 orang dari 1000 warga Jawa Tengah mengalami stress. Pada penderita gangguan jiwa, hanya $30 \%$ sampai $40 \%$ pasien gangguan jiwa bisa sembuh total, $30 \%$ harus berobat jalan dan $30 \%$ lainnya harus menjalani perawatan. Dibanding ratio dunia yang hanya satu permil, masyarakat Indonesia yang telah mengalami gangguan kejiwaan ringan sampai berat telah mencapai 18,5\% (Madalise, 2015).

Data Medikal Record Rumah Sakit Jiwa Prof. Dr. Mohammad Ildrem Medan bahwa ditahun 2014 ditemukan pasien dengan gangguan jiwa berjumlah 16.419 orang, ditahun 2015 ditemukan pasien dengan gangguan jiwa berjumlah 16.103 orang, diantaranya pasien yang dirawat inap sebanyak 2.174 orang dan pasien rawat jalan sebanyak 11.336 orang sedangkan di tahun 2016 sampai Januari 2017 jumlah pasien yang mengalami gangguan halusinasi yaitu 3.737 orang dengan pasien yang mengalami halusinasi pendengaran, yaitu sebanyak 2.616 orang.

Salah satu bentuk gangguan jiwa yang terdapat di seluruh dunia adalah skizofrenia. Skizofrenia adalah penyakit neurologis yang mempengaruhi persepsi klien, cara berpikir, bahasa, emosi dan perilaku sosialnya. Salah satu gejala yang paling sering muncul pada Skizofrenia adalah munculnya halusinasi yaitu sekitar $70 \%$ (Yosep, 2007). Nuraeni dkk (2009) menyatakan bahwa pasien dengan diagnosis madis skizofrenia sebanyak $70 \%$, halusinasi yang dialami pasien gangguan jiwa adalah halusinasi pendengaran, 20\% mengalami halusinasi penglihatan dan $10 \%$ adalah halusinasi penghidu, pengacapan dan perabaan. Berdasarkan data tersebut diketahui bahwa jenis halusinasi yang paling banyak diderita oleh pasien dengan skizofrenia adalah halusinasi pendengaran (Hidayah, 2015).

Halusinasi merupakan suatu bentuk persepsi atau pengalaman indera yang tidak terdapat stimulasi terhadap reseptornya. Halusinasi harus menjadi fokus perhatian oleh tim kesehatan karena apabila halusinasi tidak ditangani secara baik, maka dapat menimbulkan resiko terhadap keamanan diri klien sendiri, orang lain dan juga lingkungan sekitar. Hal ini dikarenakan halusinasi dengar klien sering berisikan perintah melukai dirinya sendiri maupun orang lain. Secara klinik dan evidence base, halusinasi dengar tersebut telah terbukti dapat menyebabkan distress pada individu (Keliat, 2011).

Untuk dapat menentukan perencanaan terapi yang tepat dalam mengatasi perilaku penderita tersebut, pemahaman tentang bagaimana terjadinya halusinasi ini menjadi dasar yang sangat penting bagi perawat. Penelitian yang dilakukan oleh Whitfield, Dubeb, Felitti, and Anda (2005) di san Diego dengan melakukan survey terhadap 50000 penderita psikotik menemukan bahwa halusinasi yang dialami seseorang erat kaitannya dengan masalah yang menjadi pengalaman traumatis bagi dirinya. Akan tetapi menurut Garcelan (2004) dalam artikelnya yang berjudul "A psychological model for verbal auditory hallucinations", ketika suatu proses halusinasi telah terjadi, maka pengalaman halusinasi berikutnya dicetuskan bukan oleh stres yang tinggi tapi oleh kejadian - kejadian pribadi tertentu dalam kehidupan individu yang menjadi fokus bagii dirinya (Suryani, 2010).

Penelitian yang dilakukan Engkeng, dkk (2008) tentang faktor-faktor presipitasi yang berhubungan dengan timbulnya halusinasi pada klien gangguan jiwa di BPRS Makassar, ditemukan bahwa ada hubungan antara faktor presipitasi kebutuhan tidur $(\mathrm{p}=0,0012)$, konsumsi kopi $(\mathrm{p}=0,011)$, harga diri $(\mathrm{p}=0,023)$, kecemasan $(\mathrm{p}=0,002)$ dan isolasi sosial $(\mathrm{p}=0,000)$ dengan terjadinya halusinasi, namun tidak hubungan antara presipitasi lingkungan $(p=0,296)$ dengan terjadinya halusinasi. Dari hasil wawancara peneliti terhadap 5 orang pasien halusinasi pendengaran di ruangan sibual-buali RSJ Prof.mohammad ildrem, sebanyak 3 orang pasien mengatakan bahwa pasien mengalami halusinasi pendengaran ketika keluarga tidak melibatkan klien dalam kegiatan keluarga seharihari, kurang mengajak berkomunikasi, keluarga kurang dekat dengan klien.

Berdasarkan pernyataan tersebut, seharusnya keluarga memperlakukan pasien dengan hangat, berkomunikasi dengan baik, mengikutkan dalam kegiatan sehari-hari, tapi kenyataannya pasien tidak diperlakukan sebagaimana mestinya sehingga mengalami kekambuhan. Berdasarkan hal tersebut maka peneliti tertarik untuk melakukan penelitian tentang determinan psikologis yang berhubungan dengan terjadinya halusinasi pendengaran pada pasien gangguan jiwa di ruang rawat inap RSJ Prof. Mohammad Ildrem Medan tahun 2017.

\section{B. Rumusan Masalah}

Berdasarkan latar belakang diatas, dapat dilihat bahwa masih kurangnya pemahaman keluarga dalam memperlakukan pasien di rumah, sehingga pasien cenderung mengalami halusinasi pendengaran kembali.

\section{B. Tujuan Penelitian \\ 1. Tujuan Umum}

Untuk mengetahui determinan psikologis yang berhubungan dengan terjadinya halusinasi pendengaran pada pasien gangguan jiwa di ruang rawat inap RSJ Prof.Mohammmad ildrem Medan tahun 2017.

\section{Tujuan Khusus}

a. Untuk mengetahui hubungan tindakan terlalu melindungi (over protective) terhadap terjadinya halusinasi pendengaran.

b. Untuk mengetahui hubungan antara pola asuh autoritarian terhadap terjadinya halusinasi pendengaran. 
c. Untuk mengetahui hubungan antara kurangnya perhatian terhadap terjadinya halusinasi pendengaran.

d. Untuk mengetahui hubungan interpersonal tidak harmonis terhadap terjadinya halusinasi pendengaran.

e. Untuk mengetahui hubungan konflik peran ganda terhadap terjadinya halusinasi pendengaran.

\section{Manfaat Penelitian}

\section{Bagi Pasien}

Hasil penelitian dapat memberikan informasi kepada keluarga/pasien bahwa adanya hubungan yang tidak harmonis, dan adanya peran ganda yang bertentangan dapat menyebabkan halusinasi pendengaran sehingga keluarga dapat menjaga hubungan yang lebih baik.

\section{Bagi RSJ Prof. Mohammad Ildrem Medan}

Hasil penelitian ini dapat menjadi bahan pertimbangan dalam memberikan intervensi keperawatan terhadapa pasien sehingga masalah halusinasi pada pasien dapat ditangani dengan baik.

\section{Bagi Institusi Pendidikan}

Hasil penelitian ini dapat dijadikan sebagai data base dalam mata kuliah keperawatan jiwa dan menambah bahan bacaan.

\section{Bagi Mahasiswa}

Hasil penelitian ini dapat menjadi pengalaman melakukan penelitian.

\section{Metode Penelitian}

\section{Jenis dan Desain Penelitian}

Jenis penelitian ini adalah analitik observasional, yaitu untuk mencari hubungan antar variabel. Desain penelitian ini adalah cross sectional, yaitu penelitian yang pengukuran variabel-variabelnya dilakukan hanya satu kali, pada satu saat (Sudigdo, 1995).

\section{Lokasi dan Waktu Penelitian}

Penelitian ini akan dilaksanakan di Rumah Sakit Jiwa Prof. Mohammad Ildrem Medan. Penelitian ini akan dilaksanakan pada bulan Januari-Juli 2017.

\section{Populasi dan Sampel}

Populasi dalam penelitian ini adalah 3.737 orang dengan rata-rata perbulan yaitu sebanyak 311 orang, yaitu jumlah pasien halusinasi yang dirawat inap di RSJ Prof. Mohammad Ildrem Medan mulai dari tahun 2016-Januari 2017.

Sampel dalam penelitian ini diambil dengan teknik systematic sampling. Pada cara ini ditentukan bahwa pertama kita harus menyusun daftar kerangka sampel yaitu dengan mendaftarkan jumlah seluruh sampel dimulai nomor 1 sampai 311, setelah itu sampel yang dibutuhkan yaitu 39 orang maka 311 dibagi 39 sama dengan 8, maka setiap kelipatan 8 dijadikan menjadi sampel, sampai sampel terpenuhi hingga 39 sampel jika sampel belum terpenuhi maka diulang kembali dari awal yaitu dengan kelipatan 8. (Sudigdo, 1995).

Besar sampel dalam penelitian ini diambil dengan rumus Slovin:

$$
\begin{aligned}
\mathrm{n} & =\frac{\mathrm{N}}{1+\left(\mathrm{N} \times \mathrm{e}^{2}\right)} \\
= & \frac{311}{1+(311)(0.15)^{2}}=\frac{311}{7,9}=39,3=39 \text { responden }
\end{aligned}
$$

Keterangan:

$\mathrm{n}=$ Jumlah elemen / anggota sampel

$\mathrm{N}=$ Jumlah elemen / anggota populasi

$\mathrm{e}=$ Error level $(0,15)$ (tingkat kesalahan)

Jadi, besar sampel dalam penelitian ini adalah 39 responden. Untuk memudahkan peneliti mengambil data maka peneliti menentukan kriteria inklusi dan eksklusi dalam penelitian ini, sebagai berikut:

Kriteria inklusi :

- Pasien dapat berbicara

- Pasien dapat berbahasa Indonesia

- Pasien kooperatif

- Bersedia dijadikan responden dalam penelitian Kriteria eksklusi :

- Pasien resiko melarikan diri

- Pasien resiko amuk

- Pasien yang belum terkendali

\section{Jenis dan Cara Pengumpulan Data}

Adapun jenis data dalam penelitian adalah data primer yaitu, data dari hasil wawancara langsung dengan menggunakan kuesioner kepada pasien penderita halusinasi pendengaran. Selain itu juga meggunakan data sekunder yaitu, data yang diperoleh dari Medical Record RSJ Prof. Mohammad Ildrem Medan tahun 2016 tentang pasien gangguan jiwa halusinasi pendengaran.

Adapun prosedur pengumpulan data yang akan digunakan peneliti adalah peneliti mengajukan surat penelitian dari insitusi kepada pihak bidang penelitian RSJ Prof. Mohammad Ildrem Medan. Setelah mendapatkan persetujuan dari bidang penelitian selanjutnya peneliti menunjukkan surat ijin dari bidang penelitan kepada kepala ruangan di RSJ Prof. Mohammad Ildrem Medan. Kemudian, peneliti akan mengumpulkan semua pasien dengan gangguan halusinasi serta memberikan nomor kepada masing-masing pasien untuk menentukan pasien yang akan dijadikan responden penelitian dengan ketentuan pasien yang menjadi responden adalah pasien yang mendapat angka kelipatan 8 hingga jumlah sampel terpenuhi. Setelah itu, peneliti membagikan inform consent kepada masing masing responden sebagai tanda bersedia berpartisipasi dalam pengumpulan data. Pengumpulan data akan dilakukan dengan cara mewawancarai responden satu-persatu dengan format kuesioner yang sudah dibuat oleh peneliti.

\section{Pengolahan Data}

Data yang dikumpulkan diolah dengan langkahlangkah sebagai berikut: 
a. Editing

Mengoreksi kesalahan-kesalahan dalam pengisian atau dalam data. Pada tahap ini, data yang diperoleh dilakukan pengecekan nomor responden dan memeriksa instrumen pengumpulan data.

\section{b. Coding}

Dengan memberikan kode atau tanda-tanda setiap data untuk mengklasifikasikan data yang akan diolah dengan menggunakan aplikasi SPSS. Coding data yang didapatkan setelah pengisian kuesioner adalah:

$1=\mathrm{YA}$

$2=$ TIDAK

\section{c. Scoring}

Scoring dalam penelitian ini dilakukan setelah pengukuran setiap variabel penelitian dengan kuesioner. Cara untuk menentukan scor setiap variabel yang diperoleh dari hasil jawaban dari responden menggunakan rumus sebagai berikut.

$$
\text { score }=\frac{\left(\frac{\text { nilai tertinggi -nilai terenda } h}{\text { kategori }}\right)}{\text { nilai tertinggi }} \times 100 \%
$$

Dari rumus diatas didapatkan hasil $50 \%$. Maka, apabila pasien menjawab YA $\geq 50 \% \quad(\geq 4$ pertanyaan) pada setiap variabel berarti responden mengalaminya. Apabila responden menjawab TIDAK $>50 \%$ ( $>4$ pertanyaan) berarti responden tidak mengalaminya.

\section{d. Tabulating}

Untuk mempermudah pengukuran data, maka data dimasukkan kedalam bentuk tabel distribusi frekuensi.

\section{E. Analisa Data \\ 1. Analisa univariat}

Analisa univariat bertujuan untuk menjelaskan atau mendiskripsikan karakteristik setiap variabel penelitian. Setiap variabel akan dinyatakan dengan sebaran frekuensi, baik secara angka-angka mutlak maupun secara persentase. (Notoatmodjo, 2010).

\section{Analisa bivariat}

Analisa bivariat dilakukan dengan tujuan untuk mengetahui hubungan antara dua variabel. Analisa bivariat dalam penelitian ini menggunakan uji chi square uji ini akan dilakukan dengan menggunakan aplikasi SPSS 16,0 dengan nilai signifikan $\mathrm{p}<0,15$ (terdapat hubungan yang signifikan antara variabel). (Notoatmodjo, 2010)

\section{Hasil dan Pembahasan}

\section{A. Hasil Penelitian}

Pada bab ini akan diuraikan data hasil penelitian serta pembahasan mengenai Determinan Psikologis Yang Berhubungan Dengan Terjadinya Halusinasi Pendengaran Pada Pasien Gangguan Jiwa Di Ruang Rawat Inap Rumah Sakit Jiwa Daerah Provinsi Sumatera Utara Tahun 2017. Setelah disebarkan kuesioner kepada 39 orang responden dan yang menjadi responden yaitu pasien yang mengalami Gangguan Jiwa di Rumah Sakit Jiwa Prof. Dr. Muhammad Ildrem Daerah Provinsi Sumatera Utara Medan, penelitian ini dilaksanakan pada tanggal 4 Juli s/d 6 Juli 2017, dengan hasil sebagai berikut:

\section{B. Karakteristik Responden}

\section{Umur}

Tabel 4.1 Distribusi Frekuensi Responden Berdasarkan Umur Di Ruang Rawat Inap RSJ Prof.Dr. Mohammad Ildrem Medan Tahun 2017

\begin{tabular}{|c|c|c|c|}
\hline NO & Umur & Frekunsi & Persentase \\
\hline 1 & 25-29 Tahun & 4 & 10.3 \\
\hline 2 & 30-34 Tahun & 5 & 12.8 \\
\hline 3 & 35-39 Tahun & 13 & 33.3 \\
\hline 4 & 40-44 Tahun & 14 & 35.9 \\
\hline \multirow[t]{2}{*}{5} & 45-49 Tahun & 3 & 7.7 \\
\hline & Total & 39 & 100 \\
\hline
\end{tabular}

Berdasarkan tabel 4.1 diatas diperoleh bahwa mayoritas responden adalah umur 40-44 tahun yaitu sebanyak 14 responden $(35,9 \%)$

\section{Jenis kelamin}

Tabel 4.2 Distribusi Frekuensi Responden Berdasarkan Jenis Kelamin Di Ruang Rawat Inap RSJ Prof.Dr. Mohammad Ildrem Medan Tahun 2017

\begin{tabular}{llll}
\hline No & Jenis Kelamin & Frekuensi & Persentase \\
\hline $\mathbf{1}$ & Laki-laki & 25 & 64.1 \\
$\mathbf{2}$ & Perempuan & 14 & 35.9 \\
\hline & Total & $\mathbf{3 9}$ & $\mathbf{1 0 0}$ \\
\hline
\end{tabular}

Berdasarkan tabel 4.2 diatas memperlihatkan bahwa mayoritas responden berjenis kelamin Laki-laki yaitu sebanyak 25 responden $(64,1 \%)$ 


\section{Pendidikan}

Tabel 4.3 Distribusi Frekuensi Responden Berdasarkan Pendidikan Di Ruang Rawat Inap RSJ Prof.Dr. Mohammad Ildrem Medan Tahun 2017

\begin{tabular}{llll}
\hline NO & Pendidikan & Frekuensi & Persentase \\
\hline $\mathbf{1}$ & SD & 2 & 5.1 \\
$\mathbf{2}$ & SMP & 9 & 23.1 \\
$\mathbf{3}$ & SMA & 24 & 61.5 \\
$\mathbf{4}$ & Sarjana & 4 & 10.3 \\
\hline & Total & $\mathbf{3 9}$ & $\mathbf{1 0 0}$ \\
\hline
\end{tabular}

Tabel 4.3 diatas menginformasikan bahwa mayoritas responden berpendidikan SMA sebanyak 24 responden $(61,5 \%)$.

\section{Pekerjaan}

Tabel 4.4 Distribusi Frekuensi Responden Berdasarkan Pekerjaan Di Ruang Rawat Inap RSJ Prof.Dr. Mohammad Ildrem Medan Tahun 2017

\begin{tabular}{llll}
\hline NO & Pekerjaan & Frekuensi & Persentase \\
\hline $\mathbf{1}$ & Petani & 8 & 20.5 \\
$\mathbf{2}$ & Wiraswasta & 16 & 41.0 \\
$\mathbf{3}$ & Buruh & 8 & 20.5 \\
$\mathbf{4}$ & Ibu Rumah Tangga & 5 & 12.8 \\
$\mathbf{5}$ & Pedagang & 2 & 5.1 \\
\hline & Total & $\mathbf{3 9}$ & $\mathbf{1 0 0}$ \\
\hline
\end{tabular}

Tabel 4.4 diatas menginformasikan bahwa mayoritas responden berprofesi wiraswasta sebanyak 16 responden $(41,0 \%)$.

C. Halusinasi Pendengaran

Tabel 4.5 Distribusi Frekuensi Responden Halusinasi Pendengaran Di Ruang Rawat Inap RSJ Prof.Dr. Mohammad Ildrem Medan Tahun 2017

\begin{tabular}{llll}
\hline NO & Halusinasi Pendengaran & Frekuensi & Persentase \\
\hline $\mathbf{1}$ & Ya & 27 & 69,2 \\
$\mathbf{2}$ & Tidak & 12 & 30,8 \\
\hline & Total & $\mathbf{3 9}$ & $\mathbf{1 0 0}$ \\
\hline
\end{tabular}

tabel 4.5 diatas menginformasikan bahwa mayoritas responden mengalami Halusinasi Pendengaran sebanyak 27 responden $(69,2 \%)$.

\section{Over Protective}

Tabel 4.6 Distribusi Frekuensi Responden Berdasarkan Overprotective Di Ruang Rawat Inap RSJ Prof.Dr. Mohammad Ildrem Medan Tahun 2017

\begin{tabular}{llll}
\hline No & Over Protective & Frekuensi & Persentase (\%) \\
\hline $\mathbf{1}$ & Ya & 35 & 89,7 \\
$\mathbf{2}$ & Tidak & 4 & 10,3 \\
\hline & Total & $\mathbf{3 9}$ & $\mathbf{1 0 0}$ \\
\hline
\end{tabular}

Berdasarkan tabel 4.6 diatas diperoleh data mayoritas responden mengalami over protective dari orang tua sebanyak 35 responden $(89,7 \%)$.

Tabel 4.7 Hubungan Over Protective dengan Halusinasi Pendengaran

\begin{tabular}{lllllll}
\hline \multirow{2}{*}{ Halusinasi Pendengaran } & \multicolumn{2}{l}{ Over Protective } & \multicolumn{2}{c}{ Total } & \% \\
\cline { 2 - 5 } & Ya & $\mathbf{\%}$ & Tidak & $\mathbf{\%}$ & & \\
\hline Ya & 26 & 96,3 & 1 & 3,7 & 27 & 100 \\
Tidak & 9 & 75,0 & 3 & 25,0 & 12 & 100 \\
\hline Total & $\mathbf{3 5}$ & $\mathbf{8 9 , 7}$ & $\mathbf{4}$ & $\mathbf{1 0 , 3}$ & $\mathbf{3 9}$ & $\mathbf{1 0 0}$ \\
\hline
\end{tabular}

Tabel 4.7 menginformasikan bahwa mayoritas responden yang mengalami halusinasi pendengaran juga mengalami halusinasi pendengaran juga mengalami over protective yaitu sebanyak 26 responden (96,3\%) dibanding yang tidak mengalami halusinasi pendengaran. 
E. Komunikasi

Tabel 4.8 Distribusi Frekuensi Responden Berdasarkan Komunikasi Verbal Yang Kurang Di Ruang Rawat Inap RSJ Prof.Dr. Mohammad Ildrem Medan Tahun 2017

\begin{tabular}{llll}
\hline No & Komunikasi Verbal Yang Kurang & Frekuensi & Persentase \\
\hline $\mathbf{1}$ & Ya & 33 & 84,6 \\
$\mathbf{2}$ & Tidak & 6 & 15,4 \\
\hline & Total & $\mathbf{3 9}$ & $\mathbf{1 0 0}$ \\
\hline
\end{tabular}

Berdasarkan tabel 4.8 diatas ternyata mayoritas responden mengalami Komunikasi Verbal Yang Kurang dengan ibu yaitu sebanyak 33 responden $(84,6 \%)$.

Tabel 4.9 Hubungan Komunikasi Verbal Yang Kurang dengan Halusinasi Pendengaran

\begin{tabular}{|c|c|c|c|c|c|c|}
\hline \multirow[t]{2}{*}{ Halusinasi Pendengaran } & \multicolumn{4}{|c|}{ Komunikasi Verbal Yang Kurang } & \multirow[t]{2}{*}{ Total } & \multirow[t]{2}{*}{$\%$} \\
\hline & Ya & $\%$ & Tidak & $\%$ & & \\
\hline $\mathbf{Y a}$ & 27 & 100 & 0 & 0 & 27 & 100 \\
\hline Tidak & 6 & 50 & 6 & 50 & 12 & 100 \\
\hline Total & 33 & 84,6 & 6 & 15,4 & 39 & 100 \\
\hline
\end{tabular}

Berdasarkan tabel 4.9 diatas menginformasikan bahwa mayoritas responden mengalami halusinasi pendengaran juga mengalami komunikasi verbal yang kurang yaitu sebanyak 27 responden (100\%) dibanding yang tidak mengalami halusinasi pendengaran.

F.Kurang Perhatian

Tabel 4.10 Distribusi Frekuensi Responden Berdasarkan Kurang Perhatian Di Ruang Rawat Inap RSJ Prof.Dr. Mohammad Ildrem Medan Tahun 2017

\begin{tabular}{llll}
\hline No & Kurang Perhatian & Frekuensi & Persentase \\
\hline $\mathbf{1}$ & Ya & 34 & 87,2 \\
$\mathbf{2}$ & Tidak & 5 & 12,8 \\
\hline & Total & $\mathbf{3 9}$ & $\mathbf{1 0 0}$ \\
\hline
\end{tabular}

Berdasarkan tabel 4.10 diatas memperlihatkan bahwa mayoritas responden mengalami Kurang Perhatian dari ayah sebanyak 34 responden $(87,2 \%)$

Tabel 4.11 Hubungan Kurang Perhatian dengan Halusinasi Pendengaran

\begin{tabular}{lllllll}
\hline \multirow{2}{*}{$\begin{array}{l}\text { Halusinasi } \\
\text { Pendengaran }\end{array}$} & \multicolumn{2}{l}{ Kurang Perhatian } & \multicolumn{2}{c}{ Total } & \% \\
\cline { 2 - 5 } Ya & Ya & $\mathbf{\%}$ & Tidak & $\mathbf{\%}$ & & \\
Tidak & 27 & 100 & 0 & 0 & 27 & 100 \\
\hline Total & 7 & 58,3 & 5 & 41,7 & 12 & 100 \\
\hline
\end{tabular}

Berdasarkan tabel 4.11 diatas menyatakan bahwa mayoritas responden mengalami halusinasi pendengaran juga mengalami kurang perhatian yaitu sebanyak 27 responden (100\%) dibanding yang tidak mengalami halusinasi pendengaran.

\section{G.Hubungan Interpersonal}

Tabel 4.12 Distribusi Frekuensi Responden Berdasarkan Hubungan Interpersonal Yang Tidak Harmonis Di Ruang Rawat Inap RSJ Prof.Dr. Mohammad Ildrem Medan Tahun 2017

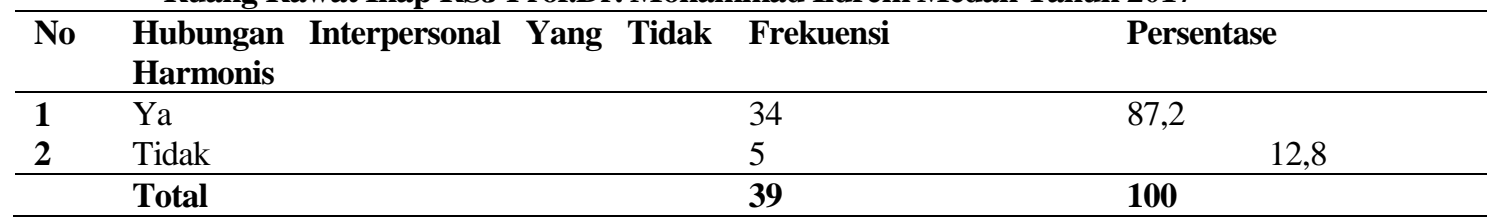

Tabel 4.12 diatas Menginformasikan bahwa mayoritas responden mengalami Hubungan Interpersonal Yang Tidak Harmonis dengan teman sebanyak 34 responden $(87,2 \%)$. 
Tabel 4.13 Hubungan Hubungan Interpersonal Yang Tidak Harmonis dengan Halusinasi Pendengaran

\begin{tabular}{llllllll}
\hline \multirow{2}{*}{ Halusinasi Pendengaran } & $\begin{array}{l}\text { Hubungan } \\
\text { Harmonis }\end{array}$ & \multicolumn{2}{l}{ Interpersonal } & Yang & Tidak & Total & \multirow{2}{*}{} \\
\cline { 2 - 6 } & $\mathbf{Y a}$ & $\mathbf{\%}$ & Tidak & $\mathbf{\%}$ & & \\
\hline Ya & 27 & 100 & 0 & 0 & 27 & 100 \\
Tidak & 7 & 58,3 & 5 & 41,7 & 12 & 100 \\
\hline Total & $\mathbf{3 4}$ & $\mathbf{8 7 , 2}$ & $\mathbf{5}$ & $\mathbf{1 2 , 8}$ & $\mathbf{3 9}$ & $\mathbf{1 0 0}$ \\
\hline
\end{tabular}

Berdasarkan tabel 4.13 diatas menunjukkan bahwa mayoritas responden mengalami halusinasi pendengaran juga mengalami hubungan interpersonal yang tidak harmonis yaitu sebanyak 27 responden (100\%) dibanding yang tidak mengalami halusinasi pendengaran.

\section{H. Konflik Peran Ganda}

Tabel 4.14 Distribusi Frekuensi Responden Berdasarkan Konflik Peran Ganda Di Ruang Rawat Inap RSJ Prof.Dr. Mohammad Ildrem Medan Tahun 2017

\begin{tabular}{llll}
\hline No & Konflik Peran Ganda & Frekuensi & Persentase \\
\hline $\mathbf{1}$ & Ya & 32 & 82,1 \\
$\mathbf{2}$ & Tidak & 7 & 17,9 \\
\hline & Total & $\mathbf{3 9}$ & $\mathbf{1 0 0}$ \\
\hline
\end{tabular}

Berdasarkan tabel 4.14 diatas diperoleh bahwa mayoritas responden mengalami Konflik Peran Ganda di keluarga sebanyak 32 responden $(82,1 \%)$.

Tabel 4.15 Hubungan Konflik Peran Ganda dengan Halusinasi Pendengaran

\begin{tabular}{|c|c|c|c|c|c|c|}
\hline \multirow[t]{2}{*}{ Halusinasi Pendengaran } & \multicolumn{4}{|c|}{ Konflik Peran Ganda } & \multirow[t]{2}{*}{ Total } & \multirow[t]{2}{*}{$\%$} \\
\hline & $\mathbf{Y a}$ & $\%$ & Tidak & $\%$ & & \\
\hline $\mathbf{Y a}$ & 25 & 92,6 & 2 & 7,4 & 27 & 100 \\
\hline Tidak & 7 & 58,3 & 5 & 41,7 & 12 & 100 \\
\hline Total & 32 & 82,0 & 7 & 18,0 & 39 & 100 \\
\hline
\end{tabular}

Berdasarkan tabel 4.15 diatas menginformasikan bahwa mayoritas responden mengalami halusinasi pendengaran juga mengalami konflik peran ganda yaitu sebanyak 25 responden $(92,6 \%)$ dibanding yang tidak mengalami halusinasi pendengaran.

\section{Hubungan Aspek Psikologis Dengan Halusinasi Pendengaran}

Tabel 4.16 Test statistic Uji Chi Square

\begin{tabular}{|l|l|}
\hline Variabel Independen & P.value \\
\hline Over Protective & 0,00 \\
\hline Komunikasi Verbal Yang Kurang & 0,00 \\
\hline Kurang Perhatian & 0,00 \\
\hline Hubungan Interpersonal yang Tidak Harmonis & 0,00 \\
\hline Konflik Peran Ganda & 0,00 \\
\hline
\end{tabular}

Tabel 4.16 memperlihatkan bahwa berdasarkan uji statistik dengan menggunakan chi square pada tingkat kemaknaan $85 \%$ dengan mentolerir kesalahan 15\% ternyata seluruh aspek psikologis mulai dari over protective, komunikasi verbal yang kurang, kurang perhatian, hubungan interpersonal yang tidak harmonis, konflik peran ganda dalam keluarga punya hubungan yang bermakna terhadap halusinasi pendengaran dengan nilai $\mathrm{p}<$ 0,15 yaitu masing - masing 0,00 .

\section{Pembahasan}

\section{Over Protective}

Pola asuh yang dianut keluarga dalam penelitian ini adalah mayoritas over protective. Pola asuh over protective adalah pola asuh orang tua yang sangat khawatir akan anaknya, takut menjadi tidak baik pada anaknya.

Dampak negatif yang ditimbulkan dari orang tua yang bersifat over- protective adalah. Anak tidak berani melakukan apapun, kecuali dia mendapat izin dari orang tuanya, Kecenderungan anak menjadi sangat pasif dan menjadi merasa takut yang berlebihan

Akibatnya orang tua yang over protektive adalah mental dan kemampuan menjadi rapuh, umumnya menjadi egois, sulit dalam bergaul, tidak tahan terhadap bantahan dan tidak sanggup menghadapi frustasi hidup sehingga mengalami masalah dalam penyesuain diri. (Kartono, 2000). 
Berdasarkan hasil penelian dari Rohmat Fatoni, (2006) mengenai hubungan antara perilaku over protective orang tua dengan penyesuaian diri remaja yang jumlah respondennya 44 orang. Hasil analisis data menunjukkan bahwa 44 siswa orang tuanya over protective, bentuk perilaku over protective ditunjukkan dengan kontak secara berlebihan dengan anak sebanyak $15 \%$ atau dialami oleh 7 siswa termasuk dalam kategori sedang, selebihnya 37 siswa atau $84 \%$ dalam kategori tinggi. Siswa yang orang tua memberikan perawatan atau memberi bantuan secara terus-menerus sebanyak $47,7 \%$ atau 21 siswa dalam kategori sedang dan 52,3\% atau 23 siswa dalam kategori tinggi. Siswa yang orang tua mengawasi kegiatannya secara berlebihan sebanyak $54 \%$ atau 24 siswa dalam kategori sedang dan 20 siswa atau 45,5\% dalam kategori tinggi. Siswa yang masalah-masalahnya senantiasa dipecahkan orang tua sebanyak $54,5 \%$ atau 24 siswa dalam kategori sedang dan sebanyak 20 siswa atau 45,5\% dalam kategori tinggi.

Bentuk perilaku over protective yang paling banyak dilakukan orang tua siswa kelas 1 SMA Negeri 1 Semarang adalah berupa kontak yang berlebihan orang tua kepada anak, orang tua senantiasa ingin dekat dengan anak, orang tua merasa khawatir bila jauh dengan anak, senantiasa ingin mengajak anak kemana orang tua pergi.

Sedangkan berdasarkan hasil penelitian yang di lakukan pada penelitian ini orang tua over protektive dengan halusinasi pendengaran mayoritas over protektive sebanyak 35 responden $(89,7 \%)$. Hal ini di akibatkan oleh orang tua yang terlalu membatasi kegiatan, memarahi bila bergaul dengan teman sebaya, melarang mengikuti trand di dalam lingkungan.

Bentuk perilaku over protective berupa kontak yang berlebihan ini dari keseluruhan subjek penelitian mencapai prosentase $84 \%$. Jika ditinjau lebih lanjut dari penyesuaian dirinya, menunjukkan bahwa sebagian besar memiliki penyesuaian diri yang sedang, hanya sebagian saja dalam kategori tinggi. Seorang individu akan mulai melepaskan diri dari keluarganya dan mulai bersosialisasi dengan lingkungannya dimulai pada masa remaja, untuk dapat bergabung dapat diterima oleh lingkungannya maka seorang remaja harus bisa menyesuaikan diri.

Surakhmad (1892:20) berpendapat, bahwa akibat perlakuan orang tua yang terlalu melindungi anaknya secara berlebihan dan cenderung mengerjakan apa saja untuk anaknya, akibatnya anak tidak mendapat kesempatan untuk belajar berbuat mandiri, mengambil keputusan, menjadi sangat tergantung pada orangtuanya, sulit untuk menyesuaikan diri dan bersikap ragu-ragu, karena perilaku orang tua yang over protective mengakibatkan seorang anak menjadi lemah hati bila jauh dari orang tua, melarikan diri dari kenyataan, mental dan kemampuannya menjadi rapuh, tidak tahan terhadap bantahan dan kritik dan sering berkonflik dengan orang lain dan biasanya tidak sanggup menghadapi frustrasi hidup. Jika seseorang tidak terbiasa menghadapi frustrasi, maka ia juga tidak terbiasa juga menghadapi kesulitan-kesulitan. Dalam proses penyesuaian diri pasti mengalami masalah, maka remaja dituntut punya pengalaman untuk menyelesaikanya sendiri, seorang remaja yang terbiasa menghadapi masalah kehidupan sehari-hari akan tahu bagaimana memecahkannya, tapi bila seorang remaja yang orang tuanya over protective tidak terbiasa mengatasi masalah, terbiasa dimanjakan dan dihindarkan dari kesulitan hidup sehari-hari kurang punya pengalaman menyelesaikan masalah. Maja wajar bila seorang remaja yang orang tuanya over protective dilingkungannya akan mengalami masalah dalam penyesuaian diri.

Berdasarkan uji statistik dengan menggunakan uji chi squere pada tingkat kemaknaan $85 \%$ dengan mentolerir kesalahan $15 \%$ pada aspek over protektive dalam keluarga mempunyai hubungan yang bermakna terhadap halusinasi pendengaran dengan nilai $\mathrm{p}<0,15$ yaitu 0,00 .

\section{Komunikasi Verbal Yang Kurang}

Pola asuh dengan halusinasi pendengaran mayoritas responden dalam penelitian ini menggunakan komunikasi verbal yang kurang. Kurangnya komunikasi verbal adalah keadaan seseorang individu yang mengalami penurunun, penundaan, atau tidak adanya kemampuan unuk menerima, memproses, mengahantarkan dan menggunakan sistem simbol.

Akibat dari kurangnya komunikasi verbal sangat mungkin memiliki resiko berperilaku antisosial, agresif, impuls dan perilaku maladaptif, misalnya membunuh, mencuri, narkoba dan sebagainya. (Prasetya, 2003)

Berdasarkan hasil penelitian dari Sambodo (2016) tentang hubungan komunikasi antara orang tua dan anak dengan agresivitas pada anak usia remaja di smk $\mathrm{x}$ magelang komunikasi antara orang tua dengan anak, terdapat 40 siswa memiliki tingkat komunikasi disfungsional $(56,8 \%)$, sedangkan sisanya yakni sebanyak 35 siswa $(43,2 \%)$ dari 81 responden memiliki tingkat komunikasi yang fungsional. Hasil penelitian menunjukkan bahwa lebih dari lima puluh persen siswa menunjukkan komunikasi dengan orang tuanya yang disfungsional. Hasil tersebut menunjukkan bahwa komunikasi yang terjadi pada anak dan orang tua kurang baik. Komunikasi yang terjadi pada orang tua dan anak yang disfungsional kemungkinan disebabkan oleh beberapa faktor antara lain adalah ketidakharmonisan keluarga, orang tua dan anak seperti yang disampaikan oleh bagian kesiswaan di sekolah yang diteliti.

Sedangkan berdasarkan hasil penelitian yang di lakukan pada penelitian ini pada aspek komunikasi verbal yang kurang dengan halusinasi pendengaran sebanyak 33 responden $(84,6 \%)$ komunikasi verbalnya kurang. Hal ini di akibatkan oleh anak yang tidak membicarakan masalah bersama orang tua, orang tua yang terlalu membuat aturan secara sepihak, memasang wajah tegang, orang tua yang selalu mengutamakan keinginannya, orang tua yang selalu menolak pendapat anak dan orang tua yang membuat aturan mutlak.

Gunarsa (2004) juga mengemukakan bahwa komunikasi efektif antara orang tua dan remaja membentuk pola dasar kepribadian remaja secara normal dan perkembangan psikologis yang sehat bagi remaja, karena merupakan hakekat seorang remaja dalam pertumbuhan dan perkembangan membutuhkan uluran tangan orang tua, orang tualah yang bertanggung jawab 
dalam mengembangkan keseluruhan eksistensi remaja termasuk kebutuhan fisik dan psikis sehingga anak dapat tumbuh dan berkembang kearah kepribadian yang matang dan harmonis.

Berdasarkan uji statistik dengan menggunakan uji chi squere pada tingkat kemaknaan $85 \%$ dengan mentolerir kesalahan $15 \%$ pada aspek komunikasi verbal yang kurang dalam keluarga mempunyai hubungan yang bermakna terhadap halusinasi pendengaran dengan nilai $\mathrm{p}<0,15$ yaitu 0,00 .

\section{Kurang Perhatian}

Pola asuh yang dianut keluarga dalam penelitian ini adalah mayoritas orang tua yang kurang perhatian terhadap anaknya. Kurang perhatian adalah orang tua yang lebih memprioritaskan kepentingannya sendiri dari pada kepentingan anak

Akibatnya dari telah meproritaskan kepentingan anak sehingga kepentingan perkembangan kepribadian anak terabaikan, tidak jarang diantara mereka yang tidak peduli atau tidak tahu sama sekali dimana anaknya berbeda, dengan siapa saja mereka bergaul, sedang apa anak tersebut bahkan anak-anak yang paling potensial terlibat obat-obatan terlarang (narkoba) dan tindakan kriminal (Prasetya, 2003).

Hasil penelitian yang dilakukan oleh (Liansyah, 2014) bahwa hasil analisis menunjukkan bahwa penyebab anak-anak di Desa Malikian putus sekolah pada jenjang pendidikan SD yaitu, kondisi kemampuan ekonomi orang tua tidak memadai, tidak ada dukungan keluarga serta kemauan anak sendiri yang tidak mau bersekolah. Hasil penelitian yang dilakukan oleh (Ni Ayu, 2014) menunjukkan bahwa ada banyak faktor penyebab anak putus sekolah usia pendidikan dasar di Kecamatan Gerokgak Tahun 2012/2013. Faktor perhatian orang tua menjadi faktor yang paling dominan karena memiliki nilai variance explained tertinggi yaitu sebesar $39,952 \%$, artinya bahwa perhatian orang tua mampu menjelaskan penyebab anak putus sekolah usia pendidikan dasar di Kecamatan Gerokgak.

Sedangkan berdasarkan hasil penelitian yang di lakukan pada penelitian ini pada aspek kurang perhatian sebanyak 34 responden $(87,2 \%)$ dengan halusinasi pendengaran. Hal ini di akibatkan oleh orang tua atau keluarga yang sibuk dan tidak mempunyai waktu, orang tua membuat jarak/ menjauh, menghindar apabila di ajak bicara, pengabaian kepentingan pribadi, acuh tak acuh terhadap masalah pribadi anak, dan selalu melupakan momen penting keluarga.

M. Dalyono (2009: 59) menyatakan bahwa faktor orang tua sangat besar pengaruhnya terhadap keberhasilan anak dalam belajar. Tinggi rendahnya pendidikan orang tua, besar kecilnya penghasilan, cukup atau kurang perhatian dan bimbingan orang tua, rukun atau tidaknya kedua orang tua, akrab atau tidaknya situasi dalam rumah, semuanya itu turut mempengaruhi pencapaian hasil belajar anak.

Berdasarkan uji statistik dengan menggunakan uji chi squere pada tingkat kemaknaan $85 \%$ dengan mentolerir kesalahan $15 \%$ pada aspek kurang perhatian dalam keluarga mempunyai hubungan yang bermakna terhadap halusinasi pendengaran dengan nilai $\mathrm{p}<0,15$ yaitu 0,00 .

\section{Hubungan Interpersonal yang tidak harmonis}

Pola asuh yang dianut keluarga dalam penelitian ini adalah mayoritas hubungan Interpersonal yang tidak harmonis. Hubungan Interpersonal yang tidak harmonis adalah hubungan yang terdiri atas dua orang atau lebih yang memilik ketergantungan satu sama lain dan menggunakan pola interaksi yang konsisten.

Berdasarkan penelitian yang di lakukan oleh Sry Ayu, 2008 tentang Hubungan Antara Komunikasi Interpersonal dalam Keluarga dengan Pemahaman Moral pada Remaja diketahui bahwa hipotesis penelitian ini ditolak, artinya tidak ada hubungan antara komunikasi interpersonal dalam keluarga dengan pemahaman moral pada remaja. Hasil penelitian ini ditolak mungkin dikarenakan adanya faktor lain yaitu faktor pola asuh orangtua dalam keluarga. Pola asuh adalah seluruh cara perlakuan orangtua yang diterapkan pada anak. Dalam keluarga, biasanya orangtua menerapkan pola pengasuhan tertentu dalam mengasuh anak mereka.

Sedangkan berdasarkan hasil penelitian yang di lakukan pada penelitian ini pada aspek hubungan interpersonal yang tidak harmonis 34 responden $(87,2 \%)$ dengan halusinasi pendengaran. Dalam aspek ini di akibatkan oleh seringnya menjadi bahan ejekan temanteman, teman yang tidak memberikan dukungan, jarang bergabung dengan kelompok teman dan selalu dianggap lemah oleh teman. Hal ini di tidak sejalan dengan penelitian terdahulu yang dilakukan oleh Sry Ayu.

Menurut Widjaya, (2000) Komunikasi interpersonal dalam keluarga sangat penting karena dengan adanya komunikasi interpersonal antar sesama anggota keluarga maka akan tercipta hubungan yang harmonis dan dapat diketahui apa yang diinginkan dan yang tidak diinginkan oleh salah satu anggota keluarga. Yang dimaksud dengan komunikasi interpersonal dalam keluarga yaitu hubungan timbal balik antara anggota keluarga untuk berbagi berbagai hal dan makna dalam keluarga. Tujuan dari komunikasi interpersonal dalam keluarga yaitu untuk mengetahui dunia luar, untuk mengubah sikap dan prilaku. Oleh karena itu dengan melakukan komunikasi interpersonal yang baik diharapkan perkembangan pemahaman moral akan berjalan baik pada seorang remaja.

Berdasarkan uji statistik dengan menggunakan uji chi squere pada tingkat kemaknaan $85 \%$ dengan mentolerir kesalahan $15 \%$ pada aspek hubungan interpersonal yang tidak harmoni dalam keluarga mempunyai hubungan yang bermakna terhadap halusinasi pendengaran dengan nilai $\mathrm{p}<0,15$ yaitu 0,00 .

\section{Konflik Peran Ganda}

Pola asuh yang dianut keluarga dalam penelitian ini adalah mayoritas pada aspek konfil peran ganda. Konflik peran ganda adalah sebagai konflik yang muncul akibat tanggung jawab yang berhubungan dengan pekerjaan mengganggu permintaan, waktu dan ketegangan dalam keluarga. 
Peran oleh Luthans (2001: 407) didefinisikan sebagai suatu posisi yang memiliki harapan yang berkembang dari norma yang dibangun. Seorang individu seringkali memiliki peran ganda (multiple roles), misalnya seseorang juga memiliki peran di keluarganya, di lingkungannya dan lain-lain. Peran-peran ini seringkali memunculkan konflik-konflik tuntutan dan konflik-konflik harapan. (Luthans, 2001: 407)

Penelitian yang dilakukan Steven Poelmans (2001) yang berjudul "Work Family Conflict as A Mediator Work Stres - Mental Health Relationship". 52 Dengan hasil penelitian yang menerangkan bahwa konflik peran ganda mempunyai pengaruh yang positif dengan stres kerja maupun dalam hubungan di dalam dunia kerja maupun masyarakat.

Sedangkan berdasarkan hasil penelitian yang di lakukan pada penelitian ini dalam aspek konflik peran ganda dengan halusinasi pendengaran mayoritas sebanyak 32 responden $(82,1 \%)$ Hal ini di akibatkan oleh anggota keluarga yang bergantung pada satu orang, keluarga yang selalu menuntut sesuatu, tidak mempunyai istirahat yang cukup karena pekerjaan, terlalu berusaha untuk memenuhi harapan keluarga dan tidak dapat mengatur waktu untuk keluarga, teman, dan pekerjaan.

Hal ini sesuai dengan menurut Sekaran (1986) ada beberapa hal yang menyebabkan terjadinya konflik peran ganda, yaitu pengasuhan anak dan bantuan pekerjaan rumah tangga, komunikasi dan interaksi dengan keluarga, waktu untuk keluarga, penentuan prioritas sebagai seorang istri, dan tekanan karir dan keluarga.

Berdasarkan uji statistik dengan menggunakan uji chi squere pada tingkat kemaknaan $85 \%$ dengan mentolerir kesalahan $15 \%$ pada aspek konflik peran ganda dalam keluarga mempunyai hubungan yang bermakna terhadap halusinasi pendengaran dengan nilai $\mathrm{p}<0,15$ yaitu 0,00 .

\section{KESIMPULAN DAN SARAN}

\section{A. Kesimpulan}

Berdasarkan hasil penelitian yang dilakukan kepada 39 responden tentang Determinan Psikologis Yang Berhubungan Dengan Halusinasi Pendengaran Pada Pasien Gangguan Jiwa di Ruang Rawat Inap RSJ Prof. Dr. Mohammad Ildrem Medan Tahun 2017, dapat disimpulkan bahwa :

1. Mayoritas responden yang mengalami Halusinasi pendengaran yang disebabkan oleh over protective sebanyak 35 orang $(87,9 \%)$.

2. Mayoritas responden yang mengalami Halusinasi pendengaran yang disebabkan oleh Komunikasi Verbal Yang Kurang sebanyak 33 orang $(84,6 \%)$

3. Mayoritas responden yang mengalami Halusinasi pendengaran yang disebabkan oleh Kurang Perhatian sebanyak 33 orang $(84,6 \%)$.

4. Mayoritas responden yang mengalami Halusinasi pendengaran yang disebabkan oleh Hubungan Interpersonal Yang Tidak Harmonis sebanyak 35 orang $(89,7 \%)$.
5. Mayoritas responden yang mengalami Halusinasi pendengaran yang disebabkan oleh Konflik Peran Ganda sebanyak 33 orang $(84,6 \%)$.

\section{B. Saran}

Berdasarkan hasil penelitian maka peneliti memberikan beberapa saran yaitu :

1. Bagi Rumah Sakit

Memberikan pendidikan kesehatan tentang faktor psikologis yang mempengaruhi halusinasi pendengaran.

2. Bagi Responden responden mengetahui faktor psikologis yang menyebabkan terjadinya halusinasi pendengaran

3. Bagi Peneliti Penelitian ini diharapkan dapat mengembangkan pengetahuan peneliti selanjutnya dan ikut berpartisipasi dalam memberikan pendidikan kesehatan bagi pasien yang mengalami halusinasi pendengaran.

\section{DAFTAR PUSTAKA}

Engkeng, Sulaemana dkk. 2008. Faktor-Faktor Presipitasi Yang Berhubungan Dengan

Timbulnya Halusinasi Pada Klien Gangguan Jiwa Di Bprs Makassar (diakses dari http://jkesmasfkm.unsrat.ac.id/wp-

content/uploads/2013/02/51.pdf pada tanggal 19 Desember 2016)

Hennessy, K. D. (2005). Work-family conflict self-efficacy: A scale validation study (diakses dari https://drum.umd.edu/dspace/bitstream/ 1903

/2526/1/umi-umd- 2410.pdf tanggal 01 Februari 2017)

Hidayah, Afifah Nur. 2015. Pengaruh Terapi Aktivitas Kelompok Stimulasi Persepsi-Sensori

Terhadap Kemampuan Mengontrol Halusinasi Pada Pasien Halusinasi Di Rsjd Dr. Amino Gondohutomo Semarang (diakses dari http://download.portalgaruda.org/article.php?

Tanggal 19 Desember 2016)

Keliat, Budi Anna. 2011. Penurunan Halusinasi Pada Klien Jiwa Melalui Cognitive Behavior Theraphy (diakses dari http://download.Portal garuda.org/article.php?article $=134679 \&$ val $=1185$ tanggal 19 Desember 2016)

Kemenkes, 2007. Direktorat Bina Pelayanan Keperawatan dan Pelayanan Medik

Dapertemen Kesehatan. Jakarta (diakses dari http://www. depkes.go .id/ article/view/13010100019/unit-kerja-eselon-2ditjen-bina-upaya kesehatan.html tanggal 14 februari 2017)

Madalise, Seniaty dkk. 2015. Pengaruh Pemberian Pendidikan Kesehatan Pada Pasien Gangguan Jiwa (Defisit Perawatan Diri)Terhadap Pelaksanaan Adl (Activity Of Dayli Living) Kebersihan Gigi Dan Mulut Di Rsj Prof.Dr. V.

L Ratumbuysang Ruang Katrili (diakses dari http:/lejournal. 
unsrat.ac.id/index.php/jkp/article/download/8142/7 702 tanggal 19 Desember 2016)

Muhith, Abdul. 2015. Pendidikan Keperawatan Jiwa. Jakarta: Andi

Muriadi, dkk. 2015. Psikologi Komunikasi. Yogyakarta: Psikosain

Notoadmodjo, Sukidjo. 2010. Metodologi Penelitian Kesehatan. Jakarta: Rineka Cipta

Prasetya, G. Tembong. 2003. Pola Pengasuhan Ideal. Jakarta: Elex Media Komputindo

Suryani, 2010. Proses Terjadinya Halusinasi Sebagaimana Diungkapkan Oleh Penderita Skizofrenia (diakses dari http://repository. unpad.ac.id/20411 /1/3Proses-terjadinya-halusinasi.pdf pada tanggal 19 Desember 2016)
Sudigdo, Sastroasmoro dkk. 1995. Dasar- Dasar Metodologi Penelitian Klinis. Jakarta: Bina Rupa Aksara

Yosep, iyus. 2007. Keperawatan Jiwa. Bandung: Refika Aditama. 